\title{
Forum
}

\section{An alternative framework for responding to the amphibian crisis}

\author{
Erin Muths and Robert N. Fisher
}

\begin{abstract}
Volumes of data illustrate the severity of the crisis affecting amphibians, where $>32 \%$ of amphibians worldwide are threatened with declining populations. Although there have been isolated victories, the current approach to the issue is unsuccessful. We suggest that a radically different approach, something akin to human emergency response management (i.e. the Incident Command System), is one alternative to addressing the inertia and lack of cohesion in responding to amphibian issues. We acknowledge existing efforts and the useful research that has been conducted, but we suggest that a change is warranted and that the identification of a new amphibian chytrid provides the impetus for such a change. Our goal is to recognize that without a centralized effort we (collectively) are likely to fail in responding to this challenge.
\end{abstract}

Keywords Amphibian decline, conservation, crisis management, emergency response, paradigm shift

$\mathrm{H}$ erpetologists have been aware that something is wrong with amphibian populations for over three decades. The identification of another lethal pathogen (Martel et al., 2014) and the lack of an immediate response is a grim reminder of the bleak outlook for this group of animals. Broad-scale assessments have quantified what we've suspected for $>20$ years (i.e. $>32.5 \%$ of amphibians are at risk, Stuart et al., 2004; and the number of amphibian populations in the USA is declining by $3.7 \%$ per year on average, including species of Least Concern, Adams et al., 2013). Since $2005>320$ peer-reviewed studies on amphibian disease have been published (based on a search in Google Scholar on 5 December 2014). Scientists and managers have addressed meetings, symposia, congressional briefings and world congresses and opined on this catastrophe of global proportions. Legitimate connections between the plight of amphibians, humans and ecosystem health have been established (e.g. Welsh \& Ollivier, 1998) and researchers have demonstrated that global amphibian decline is more than an

ERIN Muths (Corresponding author) U.S. Geological Survey, Fort Collins Science Center, 2150 Centre Ave. Bldg C, Fort Collins, Colorado, USA

E-mail muthse@usgs.gov

Robert N. Fisher U.S. Geological Survey, San Diego Field Station, San Diego, California, USA

Received 6 May 2015. Revision requested 20 July 2015.

Accepted 16 September 2015. First published online 16 December 2015. esoteric research project. We know that a variety of causes act individually, and probably synergistically, at local scales. Despite the severity of the situation and our lack of progress we have, however, made decisions to forgo action and to continue with a business as usual approach. There have, however, been small-scale successes and some useful international efforts. The Amphibian Specialist Group and the Global Amphibian Assessment collaboration between IUCN and other entities (Stuart et al., 2004) have made a concerted effort to quantify the situation and offer solutions; for example, an emergency response to immediate crises is included as a necessary mode of intervention in the Amphibian Conservation Action Plan (Gascon et al., 2007).

The Action Plan provides a cogent road map but its approach is mostly academic and lacks a mechanism for implementing the required response. The Amphibian Survival Alliance is working to implement themes from the Action Plan, but although it provides leadership (Bishop et al., 2012) it has no authority. If the situation is dire and deteriorating, then we should respond appropriately. What is missing among scientists, and in society, is an appropriate mechanism to address the problem of amphibian declines. We recognize that stop-gap measures, including the Amphibian Ark programme and other hands-on activities by zoos and resource agencies, have been initiated (e.g. Gagliardo et al., 2008) but perhaps we have arrived at a watershed moment that requires radical change and broadening of scope.

International approaches to conservation are not unprecedented. The premier example of global buy-in and cooperation in conservation is the International Union for Conservation of Nature (IUCN), which was established in 1948 and has a global membership of $>1,000$ government and non-government organizations. Its mandate includes finding pragmatic solutions to environmental challenges, supporting research, and facilitating development and implementation of policy. The reputation of this organization and its commitment to such projects as the Global Amphibian Assessment (Gascon et al., 2007) are influential; however, IUCN has no authority to enforce standards or actions (Bennett, 2011).

The International Whaling Commission, established in 1946, is another example of an international approach to a global issue. Yet despite international cooperation and decades of work it is likely that the Yangtze River dolphin Lipotes vexillifer has gone extinct, as efforts to prevent 
extinction in this unique mammal, implemented by various entities, were not effective (Turvey et al., 2007). A similar lack of accelerated response and management presage the likely extinction of the vaquita Phocoena sinus (another marine mammal, which has been declining for decades) by 2018 (Morell, 2014).

A final example of international cooperation is the Convention on Biological Diversity, initiated in 1993. By $2002>100$ governments had committed to reducing the rate of loss of biodiversity (Balmford et al., 2005). This effort may be the most cohesive from the global community, formulating specific targets and identifying mechanisms for implementation (CBD, 2015), but efforts are limited by a variety of obstacles (e.g. Puppim de Oliveira et al., 2011). These examples suggest systemic failures in the response of the global community to broad-scale conservation issues, and illustrate an alarming pattern: even when threatened species or landscapes are identified, if intervention follows traditional pathways the results are arguably ineffectual (Martin et al., 2012).

Radical means different from standard procedure, departing from historical precedent. We provide a radical prescription from re-examination of academic- and management-oriented responses to the biodiversity crisis. The feasibility of our suggestion is debatable, but our point is that radically different approaches are necessary to effectively manage the largest extinction event in modern history (Wake \& Vredenburg, 2008) and that timely actions are typically delayed by political indecision, scientific disagreement, lack of funding or lack of basic knowledge (Fisher \& Ineich, 2012). We present not the answer but an alternative strategy to facilitate rapid action in time-sensitive circumstances. Our intention is to encourage an immediate conversation that will address the impediments to the execution of timely conservation actions.

In a crisis such as a large-scale nuclear disaster governments would not measure radioactivity levels at randomly selected sites to determine exposure risk, then collect samples from a subset of citizens to determine statistically if the population was threatened. Instead, the National Incident Management System and Incident Command System would be implemented. The Incident Command System has been used widely; for example, for natural disasters, the crash of Space Shuttle Columbia, and management of exotic Newcastle disease. It is a concept of incident management standardized for use across involved entities. The system has flexibility in controlling personnel, equipment and communications, thus matching the complexity of the incident without being hindered by jurisdictional boundaries (Bigley \& Roberts, 2001; Walsh et al., 2011), and its teams are interdisciplinary, a feature critical to disaster management and already embedded in research on amphibians.

The Incident Command System, with its simple goals of clear communication, efficient resource use, and accountability, is now a common approach for incidents ranging from terrorist attacks to natural disasters. The system is used widely in the UK and the USA, with similar systems in New Zealand (Coordinated Incident Management System), Australia (Australasian Inter-Service Incident Management System), Canada (British Columbia Emergency Response Management System) and South-east Asia (Fakhruddin, 2006; USAID, 2006). The United Nations has recommended the Incident Command System as an international standard.

The system was precipitated by the California wildfires in 1970, when $>200$,000 ha burned in $<2$ weeks (FEMA, 2001; EMI, 2013) and the post-hoc assessment revealed that it was not a lack of resources to combat the fire but a lack of adequate management of those resources that precluded an effective response (Keeley et al., 2004). Similarly, we can argue that it is not a lack of resources (knowledge) that precludes progress in stemming amphibian declines, but a lack of cohesive management of the available resources. Fire management in the western USA and the history of the Incident Command System suggest that this system facilitates rapid response to crises and deals simultaneously with different situations on multiple fronts (Keeley et al., 2004). This approach is designed to make decisions and act on them quickly, correcting mistakes adaptively. A similar type of framework could be used by an international team of scientists with the authority to make difficult decisions regarding amphibian management on a global scale (sensu the Endangered Species Committee or so-called God Squad of the U.S. Fish and Wildlife Service; Abrams et al., 1998). Such a paradigm shift would facilitate decision making unencumbered by intra- and international squabbling, slow scientific debates, and bureaucracy, and replace the current ineffective strategy.

Amphibian declines can be viewed as a disaster occurring on multiple fronts. One of these fronts is disease. The identification of Batrachochytrium salamandrivorans (Bsal) in Europe (Martel et al., 2014; Yap et al., 2015), and the threat this infectious and lethal fungus poses to salamanders in the USA, is an example of where an Incident Command System approach could be applied.

The greatest diversity of salamanders exists in the USA, and Bsal, although not yet detected there, is an immediate concern because of the importation of amphibians: Schloegel et al. (2009) reported that 28 million amphibians were imported into the USA during a 6-year period, many from Asia, where Bsal originated (Martel et al., 2014). This situation requires an organized response to determine whether or not Bsal exists in the USA, adequate sampling design and strategies, and development of appropriate responses. The situation also provides an ideal test case for the implementation of an Incident Command System-type strategy. Although efforts have been mounted on multiple fronts by a variety of government, private and NGO entities, 
there is no cohesive strategy or chain of command to organize the efforts, facilitate decisions or implement actions (but see Grant et al., 2015).

Such a paradigm shift would put decision making power into the hands of a few, but with the advantages of a coordinated effort. The proposed system is modular, with specific objectives determining the size and subdivision of functional elements, which is essential in responding to multiple crises at various scales. In the case of amphibian decline, specific objectives have already been proposed (Gascon et al., 2007). A coordinated effort, using this type of hierarchy would also facilitate triage efforts (sensu Yang et al., 2006).

If conventional methods are falling short, a radical shift to an Incident Command System-type effort is worth considering. Taking action will result in errors of commission but we are beyond the point where errors of omission are acceptable. We don't presume to set forth objectives or priorities but we hope that the immediate opportunity offered by the impending Bsal epidemic and our alternative strategy will be considered before amphibian conservation decisions are reduced to academic arguments.

\section{Acknowledgements}

K. Close and A.D. Tucker provided useful comments. This is contribution number 518 of the U.S. Geological Survey Amphibian Research and Monitoring Initiative, and a product of the John Wesley Powell Center for Analysis and Synthesis Amphibian Working Group. Use of trade, product, or firm names are descriptive and do not imply endorsement by the U.S. Government.

\section{References}

Abrams, R.H., Goldfarb, W., Graham, R.L. \& Plater, Z.J.B. (1998) Environmental Law and Policy: Nature, Law and Society. West Publishing, St. Paul, USA.

Adams, M.J., Miller, D.A.W., Muths, E., Corn, P.S., Campbell Grant, E.H., Bailey, L.L. et al. (2013) Trends in amphibian occupancy in the United States. PLoS ONE, 8(5), e64347.

Balmford, A., Crane, P., Dobson, A., Green, R.E. \& Mace, G.M. (2005) The 2010 challenge: data availability information needs and extraterrestrial insights. Philosophical Transactions of the Royal Society B, 360, 221-228.

BennetT, E.L. (2011). Another inconvenient truth: the failure of enforcement systems to save charismatic species. Oryx, 45, 476-479.

Bigley, G.A. \& RoberTs, K.H. (2001) The incident command system: high-reliability organizing for complex and volatile task environments. The Academy of Management Journal, 44, 1281-1299.

Bishop, P.J., Angulo, A., Lewis, J.P., Moore, R.D., Rabb, G.B. \& Garcia Moreno, J. (2012) The amphibian extinction crisis-what will it take to put the action into the Amphibian Conservation Action Plan? SAPIENS, 5.2. Http://sapiens.revues.org/1406 [accessed 13 November 2015].
CBD (Convention on Biological Diversity) (2015) Http://www. cbd.int/convention [accessed 28 October 2015].

EMI (Emergency Management Institute) (2013) Incident Command System (ICS). Introduction to the Incident Command System I-10o.B. Http://www.training.fema.gov/is/courseoverview. aspx?code=IS-10o.b [accessed 9 December 2014].

FAKHRUDDIN, S.H.M. (2006) Incident command system for building faster responses to disaster response in the Indian Ocean Countries. Http://www.adpc.net/v2007/IKM/EVENTS\%20AND\%2oNEWS/ ADPC/2007/Oct/Abstract_ICS.pdf [accessed 28 October 2015].

Fema (Federal Emergency Management Agency) United States Fire Administration National Fire Academy (2001) Command and control of incident operations. FEMA/USFA/NFA CCIO.

Fisher, R.N. \& Ineich, I. (2012) Cryptic extinction of a common Pacific lizard Emoia impar (Squamata Scincidae) from the Hawaiian Islands. Oryx, 46, 187-195.

Gagliardo, R., Crump, P., Griffith, E., Mendelson, J., Ross, H. \& ZIPPEL, K. (2008) The principles of rapid response for amphibian conservation, using the programmes in Panama as an example. International Zoo Yearbook, 42, 125-135.

Gascon, C., Collins, J.P., Moore, R.D., Church, D.R., McKay, J.E. \& Mendelson, III, J.R. (eds) (2007) Amphibian Conservation Action Plan. IUCN/SSC Amphibian Specialist Group, Gland, Switzerland.

Grant, E.H.C., Muths, E., Katz, R.A., Canessa, S., Adams, M.J., BALLARD, J.R. et al. (2015) Salamander chytrid fungus (Batrachochytrium salamandrivorans) in the United States: Developing research, monitoring and management strategies. U.S. Geological Survey Open-File Report 2331-1258.

Keeley, J.E., Fotheringham, C.J. \& Moritz, M.A. (2004) Lessons from the October 2003 wildfires in Southern California. Journal of Forestry, 102, 26-31.

Martel, A., Blooi, M., Adriaensen, C., Van Rooij, P., Beukema, W., Fisher, M.C. et al. (2014) Recent introduction of a chytrid fungus endangers Western Palearctic salamanders. Science, 346, 630-631.

Martin, T.G., Nally, S., Burbidge, A.A., Arnall, S., Garnett, S.T., Hayward, M.W. et al. (2012) Acting fast helps avoid extinction. Conservation Letters, 5, 274-280.

Morell, V. (2014) Vaquita porpoise faces imminent extinction-can it be saved? Http://news.nationalgeographic.com/news/2014/o8/ 140813-vaquita-gulf-california-mexico-totoaba-gillnetting-chinabaiji/ [accessed 28 October 2015].

Puppim de Oliveira J.A., Balaban O., Doll C.N.H., MorenoPeñaranda R., Gasparatos A., Iossifova D. \& Suwa A. (2011) Cities and biodiversity: perspectives and governance challenges for implementing the convention on biological diversity (CBD) at the city level. Biological Conservation, 144, 1302-1313.

Schloegel L.M., Picco A.M., Kilpatrick A.M., Davies A.J., Hyatт A.D. \& Daszak P. (2009) Magnitude of the US trade in amphibians and presence of Batrachochytrium dendrobatidis and ranavirus infection in imported North American bullfrogs (Rana catesbeiana). Biological Conservation, 142, 1420-1426.

Stuart S.N., Chanson J.S., Cox N.A., Young B.E., Rodrigues A.S.L., Fischman D.L. \& Waller R.W. (2004) Status and trends of amphibian declines and extinctions worldwide. Science, 306, $1783-1786$.

Turvey S.T., Pitman R.L., Taylor B.L., Barlow J., Akamatsu T., Barett L.A. et al. (2007) First human-caused extinction of a cetacean species? Biology Letters, 3, 537-540.

USAID (2006) U.S. Indian Ocean Tsunami Warning System (IOTWS) Program. Proceedings of introductory workshop on 
'incident command system for disaster management'. Prepared for the U.S. Agency for International Development by the IRG-Tetra Tech Joint Venture. Http://nctr.pmel.noaa.gov/education/IOTWS/ ICS/ICS_SriLanka_Train_the_Trainers_Novo6.pdf [accessed 13 November 2015].

Wake, D.B. \& Vredenburg, V.T. (2008) Are we in the midst of the sixth mass extinction? A view from the world of amphibians. Proceedings of the National Academy of Sciences of the United States of America, 105, 11466-11473.

Walsh, D.W., Christen, H.T., Callsen, C.E., Miller, G.T., Maniscalco, P.M., Lord, G.C. \& Dolan, N.J. (2011) National Incident Management System. Jones and Bartlett Learning, Sudbury, USA.

Welsh, Jr, H.H. \& Ollivier L.M. (1998) Stream amphibians as indicators of ecosystem stress: a case study from California's redwoods. Ecological Applications, 8, 1118-1132.
YANG G., Bruford, M.W., Wei, F. \& Zhou, K. (2006) Conservation options for the baiji: time for realism? Conservation Biology, 20, 620-622.

Yap, T.A., Koo, M.S., Ambrose, R.F., Wake, D.B. \& VredenburG, V.T. (2015) Averting a North American biodiversity crisis. Science, $349,481-482$.

\section{Biographical sketches}

ERIN MUThs has studied declining amphibians for $>20$ years, focusing on demography and disease in mountain ecosystems and endangered species. ROBERT FISHER has studied amphibians for 25 years, with work ranging from genetics to invasive species management. Both scientists are involved in the U.S. Geological Survey's Amphibian Research and Monitoring Initiative, where they lead research on amphibians and amphibian decline issues in their regions. 